\title{
Tracing and Documenting Nazi Victims Past and Present - Introduction
}

On March 11, 1948, a letter sent from a hospital in Aylesbury, England, reached the recently established International Tracing Service (ITS) in the small town of Arolsen in Northern Hesse. It had been sent by Maria Puszkariowa, who was looking for her husband, Marian Ćwierz, whom she had lost contact with in the last months of the war: "Until 1944 he was in Schevenhütte, Schill Str. 17, near Aachen. [...]. In January 1945 he was deported from the Herne prison near Dortmund to the Buchenwald concentration camp. Since then I have had no word from him." ${ }^{1}$ This was just one of thousands of similar letters that arrived month after month in Arolsen and many other tracing offices, even three years after the end of the war. Maria Puszkariowa had sent an identical letter to the International Committee of the Red Cross in Geneva, which forwarded it to Arolsen, where it was registered two weeks later. Hundreds of thousands of people were still looking for friends and relatives who had been deported by the Germans to extermination camps, imprisoned in concentration camps and other detention facilities, or sent to the Reich for forced labor. But nearly three years after the liberation, how could the ITS find information about the fate of Marian Ćwierz in order to answer this letter? How were all of the missing persons supposed to be found - considering that millions of people had been murdered and could not come forward themselves, and that the confrontation between East and West had divided Germany and Europe, meaning it was often impossible to search for clues at the sites of persecution?

Personal documents were an important component in the effort to answer these questions - documents the Germans had produced for the purposes of persecution, but also documents the Allies had used to register and care for liberated prisoners. From the late 1940s onward, more than 30 million such documents were gathered in Arolsen. This resulted in the creation of one of the world's largest collections of documents on the victims of Nazi persecution, which is now being preserved, described and made publicly accessible by the

1 The letter from Maria Puskariowa was addressed to the Central Tracing Bureau, the predecessor to the ITS, and bears the incoming mail stamp of the CTB, 11.3.1948, 6.3.3.2/90584689/ITS Digital Archive, Arolsen Archives.

Ә OpenAccess. (c) 2020 Henning Borggräfe, Christian Höschler, Isabel Panek, published by De Gruyter. (c) BY-NC-ND This work is licensed under the Creative Commons Attribution-NonCommercial-NoDerivatives 4.0 License. https://doi.org/10.1515/9783110665376-002 
Arolsen Archives. ${ }^{2}$ The holdings include extensive documents from the Buchenwald concentration camp, which were secured by the US Army when the camp was liberated and were later made available for tracing purposes. According to these documents, Marian Ćwierz had been arrested in July 1944 in Meschede before being deported from the Herne police prison to Buchenwald as a political prisoner on January 6, 1945, by order of the Dortmund Gestapo. When he was registered in the camp, all of his personal belongings and a suitcase of clothing were taken from him. These personal effects, as they are known, were dispersed by the SS shortly afterwards, meaning that the property of the Polish forced laborer was distributed to the German population. Just three days after Marian Ćwierz arrived in Buchenwald, the SS transported him to the Ohrdruf S III subcamp, where the prisoners were forced to dig tunnels. He survived the murderous conditions in this camp for only a few weeks. As in tens of thousands of other cases, the ITS had to send his wife the sad news in May 1948 that, according to the concentration camp documents, her husband had died on March 22, 1945. ${ }^{3}$

The correspondence pertaining to the search for Marian Ćwierz can now be found in Tracing/Documentation file (T/D file) number 34. This was one of the first of a total of over three million case files that the ITS created starting in 1948 and that continue to be created by the Arolsen Archives. To this day, the Arolsen Archives receive around 15,000 inquiries annually relating to more than 20,000 people. ${ }^{4}$ When an inquiry is first received about a person, a $T / D$ file is opened (though today these files are only digital). All further correspondence about the case, as well as any subsequent inquiries received about the person from other relatives or authorities, are also placed in this file. ${ }^{5}$ If they were stacked on top of one another, the huge volume of $T / D$ files would reach a height of 6,476 meters, towering almost as high as Mont Blanc, the highest mountain in the Alps - and providing the title of this book. The terms tracing and documenting also delineate the subject matter addressed by these articles.

2 In May 2019, the name of the ITS was changed to the Arolsen Archives - International Center on Nazi Persecution. Regarding the history of the Arolsen Archives, see Henning Borggräfe, Christian Höschler and Isabel Panek (eds.): A Paper Monument: The History of the Arolsen Archives, Exhibition Catalogue, Bad Arolsen: Arolsen Archives, 2019.

3 ITS to Maria Puskariowa, 19.5.1948, 6.3.3.2/90584692/ITS Digital Archive, Arolsen Archives. See also Buchenwald Prisoner Documents on Marian Ćwierz, 1.1.5.3/5707125/ITS Digital Archive, Arolsen Archives; KZ Buchenwald, verstorbene Häftlinge in Außenkommando S III, 5.4.1945, 1.1.5.1/5347901/ITS Digital Archive, Arolsen Archives.

4 See https://arolsen-archives.org/en/living-history/annual-report-2018/. Last accessed: 8.8. 2019.

5 Most of these files are found in sub-collection 6.3.3.2 Repository of $T / D$ cases; other case files are in the other sub-collections of Group 6.3.3 ITS Case Files as of 1947. 
In its original sense, tracing meant an active search for missing persons. The direct predecessor to this activity was the search for prisoners of war and missing civilians during the First World War by the International Committee of the Red Cross in Geneva. ${ }^{6}$ The methods used for this included local investigations, correspondence with other tracing offices and authorities (such as resident registration offices or registry offices), compiling lists of names with findings (such as where individuals had been held or had died), and transferring this information to card files. In view of the scale of persecution in the Second World War, which left millions dead, tracing after 1945 quickly came to mean the evaluation of documents seized from Nazi authorities, as well as those that had been gathered by the Allies for the care of Displaced Persons (DPs), in the hopes that they might contain clues about missing individuals. The clarification of fates became another important term in this context.

In the late 1940 s and early 1950 s, these collected documents began to attract the attention of other entities, namely, German compensation authorities and the immigration authorities of many different countries which wanted to use historical sources to review claims and entry applications. Survivors, family members and their legal representatives also contacted the ITS to request documents proving that they had been persecuted or showing where they were after the war. In light of this, the ITS changed the name of its correspondence files in 1954 from $T$ files (for tracing) to the above-mentioned $T / D$ files, because the documents initially used for tracing were increasingly also being used for documenting the victims of Nazi persecution. ${ }^{7}$

Tracing and documenting thus overlapped when it came to evaluating the archival documents for information about individuals - and these activities continue to overlap at the Arolsen Archives today. Many $T / D$ files testify to this dual use in that they contain both early correspondence pertaining to tracing and the clarification of fates and later correspondence pertaining to compensation or immigration proceedings. Finally - reflecting an even later transformation of the tracing process - the $T / D$ files often include inquiries from the children or grandchildren of victims of the Nazis who want to learn more about their family history.

Documenting has yet another meaning in this context. It refers to the evaluation of historical documents, but in a broader sense it stands for the decadeslong efforts of the ITS and many similar institutions to purposefully collect and organize these documents. It additionally represents the resulting creation of

6 See the chapter by Christian Höschler and Isabel Panek in this volume.

7 The cover of the file for Marian Ćwierz also bears the label " $T$ file." 
new collections of source materials, which are themselves historically valuable for researching victims of Nazi persecution. The collection of $T / D$ files is a very good example of this. Documenting applies not only to the institutions that were established as tracing services, however, but also to those concerned primarily with the compensation of victims or prosecution of perpetrators, and to institutions founded for the purposes of remembrance and commemoration. They all documented victims of Nazi persecution using a variety of methods, and they created their own archives to do so.

The search for missing persons and documentary proof of persecution has occupied millions of victims and their relatives since 1945. Added to this are numerous institutions that were either established specifically for tracing and documenting or that pursued one or both of these activities as key tasks. We therefore consider tracing and documenting to be an important aspect of the second history $^{8}$ of National Socialism, meaning it is one of the fields that has attempted to reckon with the crimes of the Nazis since 1945. But this field has been given scant attention by scholars to date, and its importance to the victims of Nazi persecution and their families has not been sufficiently appreciated - unlike the compensation of Nazi victims, prosecution of Nazi perpetrators and development of public memory, which are comparatively well-researched fields. ${ }^{9}$

Tracing and documenting were largely overlooked by researchers for a long time compared to these three other fields, probably in part because the millions of individual tracing and documenting activities mostly took place out of the public eye - unlike criminal prosecution and commemoration - and were often conducted directly between the tracing and documentation offices on the one hand and the survivors and their relatives on the other. This also meant they were rare-

8 Peter Reichel, Harald Schmid and Peter Steinbach (eds.): Der Nationalsozialismus: Die zweite Geschichte: Überwindung, Deutung, Erinnerung, Munich: Beck, 2009.

9 Regarding the compensation of victims of Nazi persecution, see most recently Constantin Goschler (ed.): Compensation in Practice: The Foundation "Remembrance, Responsibility and Future" and the Legacy of Forced Labour during the Third Reich, New York/Oxford: Berghahn, 2017; on criminal prosecution, see Enrico Heitzer, Günter Morsch et al. (eds.): Im Schatten von Nürnberg: Transnationale Ahndung von NS-Verbrechen, Berlin: Metropol, 2019; Kerstin Hofmann: "Ein Versuch nur - immerhin ein Versuch": Die Zentrale Stelle in Ludwigsburg unter der Leitung von Erwin Schüle und Adalbert Rückerl (1958-1984), Berlin: Metropol, 2018; regarding public memory, see Johannes Rhein, Julia Schumacher and Lea Wohl von Haselberg (eds.): Schlechtes Gedächtnis? Kontrafaktische Darstellungen des Nationalsozialismus in alten und neuen Medien, Berlin: Neofelis, 2019, and the conference proceedings from Geteiltes Gedächtnis? Erinnerung an die NS-Zwangsarbeit im Europa des 21. Jahrhunderts, 9.3.2016-11.3.2016, Hamburg, in: H-Soz-Kult, 14.9.2016. Available at: https://www.hsozkult.de/conferencereport/id/tagungsberichte-6697. Last accessed: 9.8.2019. 
ly a topic of public discussion, as compensation was. At the same time, however, the institutions involved in tracing and documenting have always had many points of contact with these three widely researched fields of second history, a fact addressed by a number of the essays in this volume.

This book is based largely on an international conference held in October 2018 in Bad Arolsen with the title Tracing and Documenting Victims of Nazi Persecution: History of the International Tracing Service (ITS) in Context. ${ }^{10}$ The conference was linked to ongoing research for the first permanent exhibition on the history of the Arolsen Archives that opened in June 2019. One aim of the conference was to discuss new research findings on the institution's history in a broader context. The goal was also to look at the full history of tracing and documenting - in terms of the many institutions that were active in this field particularly in the early post-war period, and with an eye to important turning points or processes of change and the reasons for them in the seven decades since the end of the Second World War.

In May 2017, after the documents of the German Kirchlicher Suchdienst (Church Tracing Service) were handed over to the German Federal Archives, a conference was held in Bayreuth dealing with tracing services and archival work. The Church Tracing Service had been responsible primarily for German expellees and refugees after 1945. ${ }^{11}$ Then, in December 2018, Yad Vashem organized a conference entitled Searching for Each Other: Survivors' Attempts in the Post-War Period to Locate Missing Relatives and Friends, which focused specifically on the search for victims and survivors of the Holocaust. ${ }^{12}$ These conferences not only indicate growing interest in the topic, they also show that tracing and documenting were not limited to Nazi victims after 1945. The International Committee of the Red Cross in Geneva, like many national tracing offices (which were often attached to local Red Cross societies), was concerned with everyone missing after the war. In occupied Germany, however, strictly separated structures were established for tracing foreigners from UN countries and victims of Nazi persecution

10 Conference proceedings from Tracing and Documenting Victims of Nazi Persecution: History of the International Tracing Service (ITS) in Context, 8.10.2018-9.10.2018, Bad Arolsen, in: HSoz-Kult, 29.1.2019, www.hsozkult.de/conferencereport/id/tagungsberichte-8071. Last accessed: 9.8.2019.

11 Conference proceedings available at: https://www.bundesarchiv.de/DE/Content/Artikel/ Ueber-uns/Aus-unserer-Arbeit/Textsammlung-Konferenz-Bayreuth-2017/2017-11-30_suchdiensteund-archivarbeit_laa.html?chapterId=36974. Last accessed: 9.8.2019.

12 "Searching for Each Other: Survivors Attempts in the Post-War Period to Locate Missing Relatives and Friends". Available at: https://www.yadvashem.org/sites/default/files/newsletters/ files/Workshop\%20Program\%20Zborowski.pdf. Last accessed: 9.8.2019. 
on the one hand, and German expellees, war victims and missing Wehrmacht soldiers on the other.

Although it would seem worthwhile to adopt an overarching perspective here, particularly in terms of documenting the history of tracing methods and the public discussion of the search for missing persons in the twentieth century, ${ }^{13}$ scholars to date have continued to follow this separation established by the Allies. Additionally, in the interest of anchoring the topic of tracing and documenting more firmly in the second history of National Socialism, it makes sense to initially focus solely on the tracing and documenting of Nazi victims.

A moderate amount of research has been conducted to date. It is dominated by individual studies on the organizational history of various tracing and documentation offices. These were initially published mainly by the tracing institutions themselves, usually to mark memorial days or institutional anniversaries. They provide overviews of the tasks and goals of the tracing and documentation offices and are aimed primarily at the employees of similar institutions and interested members of the general public. Considering the context in which they were produced, many of them must be considered source materials rather than scholarly accounts. ${ }^{14}$ It is only more recently that the topic of tracing and documenting has attracted the attention of historians. But the emphasis here is still very much on the early history of the search for missing victims of the Nazis in the immediate post-war period. The tracing of displaced children has also become a focal point in recent years - a trend reflected in other thematically related areas of research. ${ }^{15}$

When it comes to the topic of documenting, by contrast, a large number of studies have been produced. These are not positioned in a dedicated field of re-

13 For research in this area with a broader perspective extending even beyond the Second World War, see Jenny Edkins: Missing: Persons and Politics, Ithaca: Cornell University Press, 2016.

14 Deutsche Dienststelle (WASt) (ed.): Narben bleiben: Die Arbeit der Suchdienste 60 Jahre nach dem Zweiten Weltkrieg, Kassel: Volksbund deutscher Kriegsgräberführsorge, 2007; International Tracing Service (ITS) (ed.): 60 Years of History and Benefit of the Personal Documentary Material about the Former Civilian Persecutees of the National Socialist Regime Preserved in Bad Arolsen, Bad Arolsen: International Tracing Service, 2003.

15 Verena Buser: "Child Survivors and Displaced Children in the Aftermath Studies: An Overview”, in Henning Borggräfe, Akim Jah, Steffen Jost and Nina Ritz (eds.): Freilegungen: Rebuilding Lives - Child Survivors and DP Children in the Aftermath of the Holocaust and Forced Labor, Göttingen: Wallstein, 2016, 27-39; Julia Reus: “Everywhere where human beings are, we can find our children”: On the Organization of the ITS Child Search Branch Files”, ibid., 41-49. See also Lynne Taylor: In the Children's Best Interests: Unaccompanied Children in American-Occupied Germany, 1945-1952, Toronto: University of Toronto Press, 2017. 
search, however, but instead must be considered contributions to Holocaust aftermath studies ${ }^{16}$ or research into the politics of history. For this reason, such works revolve less around the practical documentation activities of the respective institutions and more around the depiction and analysis of debates relating to the politics of the past. ${ }^{17}$

Greater attention has been paid to the history of the ITS in recent years, however. In 2011, Arolsen historian Bernd Joachim Zimmer published a detailed account of the organization's early administrative history. ${ }^{18}$ A dissertation by historian Jennifer Rodgers looked at the creation and development of the ITS in the context of the conflict between East and West and showed how different international players used the archive for their own political gains during the Cold War. And on a scholarly meta-level, Dan Stone has investigated the potential and challenges of the ITS collection for producing a social history of the Holocaust and Nazi persecution. ${ }^{19}$ When the Research and Education department of the ITS was established after the archive reopened to the public in 2007, research began to be conducted into the thematic areas covered by the collections in what are now the Arolsen Archives, including the death marches, life trajectories of Displaced Persons, early testimonies of victims of Nazi persecution, and the persecution and compensation of forgotten victims. ${ }^{20}$ And the new permanent ex-

16 Eleonora Bergmann: "Early accounts of survivors: The records of the Central Jewish Historical Commission at the Jewish Historical Institute in Warsaw”, in René Bienert, Rebecca Boehling and Susanne Urban (eds.): Freilegungen: Überlebende - Erinnerungen - Transformationen, Göttingen: Wallstein, 2013, 138-151; Boaz Cohen: "The difficulties of creating a Holocaust archive: Yad Vashem and Israel Kastner 1947-1948”, in Jewish Culture and History, 15/3, 2014, 173-187; Laura Jockusch: Collect and Record! Jewish Holocaust Documentation in Early Postwar Europe, Oxford: OUP, 2012.

17 Matthias Haß: Gestaltetes Gedenken: Yad Vashem, das U.S. Holocaust Memorial Museum und die Stiftung Topographie des Terrors, Frankfurt/New York: Campus, 2002; Carola Lau: Erinnerungsverwaltung, Vergangenheitspolitik und Erinnerungskultur nach 1989: Institute für nationales Gedenken im östlichen Europa im Vergleich, Göttingen: V\&R unipress, 2017; Edward Tabor Linenthal: Preserving Memory: The Struggle to Create America's Holocaust Museum, New York: Viking, 1995.

18 Bernd Joachim Zimmer: Der Internationale Tracing Service Arolsen: Von der Vermisstensuche zur Haftbescheinigung: Die Organisationsgeschichte eines "Ungewollten Kindes" während der Besatzungszeit, Bad Arolsen: Waldeckischer Geschichtsverein, 2011.

19 Jennifer Rodgers: From the 'Archive of Horrors' to the 'Shop Window of Democracy': The International Tracing Service and the Transatlantic Politics of the Past, Phd Diss., University of Pennsylvania, 2014; Dan Stone: "The Memory of the Archive: The International Tracing Service and the Construction of the Past as History”, in Dapim: Studies on the Holocaust, 31/2, 2017, 69-88. 20 Jean-Luc Blondel, Susanne Urban and Sebastian Schönemann (eds.): Freilegungen: Auf den Spuren der Todesmärsche, Göttingen: Wallstein, 2012; Henning Borggräfe, Hanne Leßau and Har- 
hibition that opened in June 2019, entitled A Monument of Paper: The History of the Arolsen Archives, takes a critical and reflective look at the varied history of the institution. ${ }^{21}$

In a broader and more general sense, tracing and documenting are important aspects of transitional justice, or the establishment of justice in the transition from unjust systems to new forms of social and political coexistence. Tracing and documenting remain necessary tasks in the wake of wars and dictatorships in the twenty-first century as well. For example, an extensive body of specialized social-scientific and legal literature has been produced to deal specifically with the topic of enforced disappearance, which has been used a method of terror in conflicts since the second half of the twentieth century. ${ }^{22}$ While this literature is very distinct from historical studies of the repercussions of World War II, taking it into consideration could open up interesting perspectives in terms of methodology and content for future research into the tracing and documenting of Nazi victims.

The goal of the book at hand is initially much more modest. It aims to bring together important aspects of the existing research on tracing and documenting in order to stimulate further research in this still underexposed area of study. The opening article grapples with a question that is closely tied to the subject of the book, but that also cuts across it: How can the paper legacy of seven decades of tracing and documenting be put to use today for research as well as educational and memorial work? The benefits and disadvantages of the ITS archive are the subject of the chapter by Dan Stone, based on a keynote presentation, which illuminates core elements of the collections of the Arolsen Archives from an epistemological perspective and demonstrates how the collections can be used for a social history of the Holocaust and Nazi persecution. Many of the essays under the heading From Early Tracing Activities to Information for Descendants look at the historical development of the clarification of fates and how the need for in-

ald Schmid (eds.): Fundstücke: Die Wahrnehmung der NS-Verbrechen und ihrer Opfer im Wandel, Göttingen: Wallstein, 2015; Akim Jah and Gerd Kühling (eds.): Fundstücke: Die Deportation der Juden aus Deutschland und ihre verdrängte Geschichte nach 1945, Göttingen: Wallstein, 2016. For a comprehensive list of a number of publications by the Arolsen Archives, see https://ar olsen-archives.org/en/publications-downloads/. Last accessed: 9.8.2019.

21 Henning Borggräfe, Christian Höschler and Isabel Panek: A Paper Monument; an online tour of the exhibition is available at: www.arolsen-archives.org/exhibition. Last accessed: 28.8.2019. 22 See, for example, Gabriel Gatti: Surviving Forced Disappearance in Argentina and Uruguay, New York: Palgrave Macmillan, 2014; Council of Europe, Commissioner for Human Rights (ed.): Missing Persons and Victims of Enforced Disappearance in Europe, 2016. Available online at: https://www.refworld.org/docid/572233704.html. Last accessed: 28.8.2019. 
formation and the practice of providing it have changed from the immediate post-war period to the present day.

The editors Christian Höschler and Isabel Panek provide an introductory overview of the early search for missing victims of the Nazis, particularly taking into account the activities of survivors, the early history of the ITS and the methods and tools that were used for tracing and clarifying fates, which have not yet been specifically studied by scholars. The search for Jewish victims of Nazi persecution is the subject of the chapter by Linda G. Levi, which looks at the activities of the American Jewish Joint Distribution Committee as well as the particular challenges of searching for survivors of the Holocaust and the associated issue of reuniting families. Christine Schmidt's article on the situation in Great Britain is a national case study that not only discusses tracing and the clarification of fates primarily in the context of Jewish migration, but also shows how the activities of the British Red Cross Society laid important foundations for the subsequent centralized tracing and documentation of Nazi persecution in Europe. The chapter by Maren Hachmeister, by contrast, turns the spotlight to Eastern Europe and explores the activities of the national Red Cross Societies of Poland and Czechoslovakia. It highlights the specifics of the search for Nazi victims in these two states while also revealing the global dimension of their work through their cooperation with international actors such as the ITS. With his chapter on the work of Simon Wiesenthal, René Bienert contributes a case study that uses Austria as an example of the engagement of survivors of Nazi persecution after 1945. One central finding is that the search for missing persons was sometimes carried out in the context of other activities - in this case, as part of the search for Nazi perpetrators. Silke von der Emde takes a literary studies approach to examining the role of Displaced Persons in the early years of the ITS. As survivors of Nazi persecution, they were not only the subject of many of the documents preserved in the archive, they were also involved in shaping the growing collection in Arolsen as an archive of feeling and making empathy an important component of tracing activities. Other chapters in this volume show how the focal points of tracing gradually changed and which additional tasks arose over the course of seven decades. Zvi Bernhardt, for example, describes how the Yad Vashem memorial played an insignificant role in the search for Holocaust victims for nearly three decades before developing into a key actor in the 1980s, one which continues to carry out this task in Israel today. Diane Afoumado offers an overview of the current information practices of the United States Holocaust Memorial Museum (USHMM), with a focus on the critically important use of the digital collections of the Arolsen Archives and the special aspects of providing information about Holocaust victims to second- and third-generation relatives. Finally, Ramona Bräu, Kerstin Hofmann and Anna Meier-Osiński document the many different 
layers of today's tracing at the Arolsen Archives in terms of the changing needs for information, the professionalization of the organization's visitor services and the \#StolenMemory campaign, the aim of which is to return the personal effects stored in the Arolsen Archives to the relatives of the former concentration camp prisoners to whom they belonged.

The title of the second part of this book is Collections and Activities of Archives Dealing with Nazi Victims. The chapters in this section focus not on tracing and the clarification of fates, but rather on the farther-reaching activities and spheres of action of institutions with collections on the topic of Nazi persecution - including the acquisition of relevant documents, the establishment and preservation of collections, and the aspects of politics and memory culture that are tied up with the work of such institutions. Using the example of the Arolsen Archives, the introductory essay by the editors Henning Borggräfe and Isabel Panek identifies the characteristics of what are known as collections archives and explains not only the creation and structure of the ITS archives, but also their (in)accessibility for historical research and public memory over the course of decades. Rebecca Boehling considers the influence of international actors in her analysis of the transformation of the ITS from a pure tracing service to a place of documentation, research and remembrance of Nazi persecution, and shows how this transformation significantly affected the importance to memory culture of the documents now preserved in the Arolsen Archives. In his chapter about the German Federal Archives as an actor in German politics of memory, Tobias Herrmann describes various activities at the institution that contribute to the reckoning with Germany's Nazi past. He makes a distinction between legally defined responsibilities and activities that result from the self-conception of the German Federal Archives as a part of present-day memory culture. Carola Lau compares the creation, reception and impact of state documentation and research institutions in Poland, Slovakia and the Czech Republic. Her article focuses on the significance of the Nazi period for the work of what are known as Institutes of $\mathrm{Na}$ tional Remembrance at the intersection between memory management, memory culture and the politics of the past in each country. The last chapter in this book is by Puck Huitsing and Edwin Klijn, who use the example of the Dutch War Collections project to examine current developments in the digitization of historical collections and public access to them. The authors see great potential in the systematic archival description and linking of digital holdings to enable new possibilities and approaches to discoverability and evaluation.

Although this volume once again pays special attention to the history of what was the ITS and is now the Arolsen Archives, our explicit goal is to consider the full spectrum and development of the field - not least in order to better understand what was unique about the history of the ITS or exemplary for other 
institutions and their respective fields of activity (even if only in certain periods of time). It would be interesting for future studies to look beyond the perspective of individual organizations and attempt an overarching history of the process of tracing and documenting Nazi victims. One important aspect of this, which is unfortunately entirely missing from this volume and all previous studies, would be an analysis that goes beyond the depiction of individual cases to recount the history of tracing and documenting from below, from the perspective of the people affected - first of the survivors and relatives of the missing themselves, then of the subsequent generations. The extensive $T / D$ files of the ITS and similar collections of files from other organizations offer ample empirical material for this.

Our thanks go to everyone who contributed to the conference and to this volume, as well as to Sarah Hudson, Jessica Spengler and Anne-Marie Wilms for translating selected articles, and to Anna Metta and Margit Vogt for their editorial support. We would like to thank De Gruyter Oldenbourg, in particular Martin Rethmeier and Jana Fritsche, for the trust placed in us with the establishment of a new Arolsen Research Series; the book at hand is the first volume in this series. In addition to the printed book, a free and fully accessible version of the text is available online at https://doi.org/10.1515/9783110665376-002 in the interest of the open access philosophy of the Arolsen Archives. Finally, special thanks are due to our colleagues at the Arolsen Archives who, in various ways, supported the production of this book and the organization of the conference that preceded it. 
